\title{
The Development of Micro and Small Enterprises of Sintrong Leaf Chips in Cilacap District
}

\author{
Anah Furyanah ${ }^{1}$, Haidilia Maharani ${ }^{2}$, Siti Alfiah ${ }^{3}$, Jeni Andriani ${ }^{4}$ \\ \{dosen01816@unpam.ac.id ${ }^{1}$,dosen02006@unpam.ac.id²,dosen01670@unpam.ac.id ${ }^{3}$ \} \\ Universitas Pamulang, Tangerang Selatan ${ }^{1}$, Universitas Pamulang, Tangerang Selatan ${ }^{2}$, Universitas \\ Pamulang, Tangerang Selatan ${ }^{3}$, Universitas Pamulang, Tangerang Selatan ${ }^{4}$
}

\begin{abstract}
The objectives of this study are to describe and analyze the development of Micro and Small Enterprises (MSE's) of sintrong leaf chips as well as the obstacles of the development of sintrong leaf chips in Kuta Agung Village, Dayeuhluhur Sub-District, Cilacap District. The method used in this study was a qualitative descriptive method with data collection technique of purposive sampling by means of interview and desk study. Data analysis was made through phases according to Miles and Huberman, 1984 (Alfiah, Jeni, Anah, 2020). The result of this study is that MSE's of sintrong leaf chips have strong internal potency and it needs support from the external party, namely the relevant government office in Cilacap District. MSE's of sintrong leaf chips has some obstacles, such as limited human resources, limited access to capital, limitation on market access, limited facilities and infrastructure, the introduction of new product and a quite simple packaging.
\end{abstract}

Key Words: Micro and Small Enterprises (MSE's), Development, Sintrong Leaf

\section{Introduction}

\subsection{Background of Problem}

Indonesia is an agrarian country that has abundant natural resources inside. Human resources should be able to make use such natural resources owned by the country which is conferred by God to Indonesian people. The processing of natural resources shall be beneficial for the prosperity of people by improving the economic capability of the people. Various kinds of trees and plants can live in the nature of Indonesia luxuriantly according to the existing season in Indonesia, namely tropical conditions with rain and dry climate.

The Government always encourages people to be able to process such natural resources of Indonesia in various kinds of ways, both the aspects of laws and regulations as well as funds support. According to its main program, The Food Security Agency of the Ministry of Agriculture has implemented four (4) programs in 2019, as follows:

a) Development of the availability and overcoming Food Insecurity.

b) Development of distribution system and food price stability.

c) Development of diversity of consumption and food security.

d) Management and other technical support to Food Security Agency [1] 


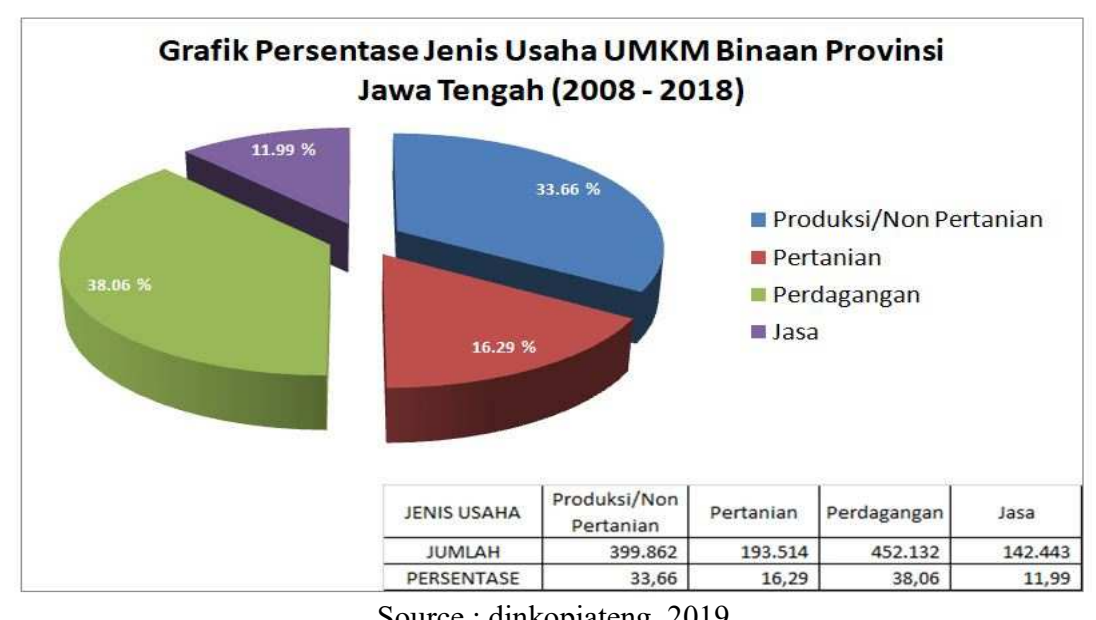

Source : dinkopjateng, 2019

Fig.1. Graph of the percentage of MSME businesses.

Based on the above graph, it can be seen that the growth of MSE's under the guidance of Central Java Province in the field of agriculture has a slight achievement of 16,29\%. It is still dominated by MSEs in the field of production/non-agriculture of 33,66\%, trading of 38,06\% and services of $11,99 \%$. [2]

Many efforts have been conducted by various kinds of levels, from small to large-scale of businesses. It starts from the business in the field of agriculture up to business in the field of trading. The field of agricultural food starts its business of foods from plants or fishes or animals. Business in the field of food can start by the making of chips from sintrong leaf. Sintrong leaf is mostly found in the villages, roadside, at deserted land or at yard in a mountain area with the elevation above 200 meter above the sea level. [3]

Sintrong leaves are wild grass where our parents in the past often use them for salad both unprocessed and processed vegetable salad and it is not cultivated because it grows automatically as weeds. As for other chips, this sintrong leaf contains high nutrition and benefit for the people if it is consumed properly. The utilization sintrong leaf into chips will have a value-added so that it can improve the economy of the people. It has happened in Kuta Agung Village, Dayeuhluhur Sub-District, Cilacap District which is located at western of Central Java which is directly bordered to Kuningan, West Java. To arrive at that place, we should pass through uphill with a tortuous sharp turn of the road. There are still many wild grasses or plants called Sintrong in this village. A housewife in this Kuta Agung Village makes use of this wild plant not only as salad, but also made chips which are mixed with flour. Thus, it becomes a product called sintrong leaf chips. In the beginning, she makes it for her consumption, but when time passes by, many people have tried and interested to make it as it is tasteful. Therefore it needs to be developed. Marketing is just conducted in the stall near the house and local market. [4] If the people have known the taste and benefit of sintrong leaf chips, it assumes that it will increase the reach of extensive marketing. For this present time, it is not so extensive because not so many people know about such sintrong chips. There are wild plants of sintrong leaf that contains nutritional benefits, but many people do not know yet the added-value of sintrong leaf.

Sintrong leaf chips are just made for the first time and in few amounts in Kuta Agung Village, Dayeuhluhur Sub-District, Cilacap District. Sintrong leaf chips originate from wild plants and have many benefits, it will be more interesting if they are packed in interesting forms 
and developed well by making use of the existing opportunities in order to improve the prosperity of the people in the field of economy through Micro and Small Scale of Business of sintrong leaf chips. The scope of marketing is still not extensive for sintrong leaf chips. Therefore, the writer is interested to research the development of micro and small scale of business of sintrong leaf chips. This research is titled "The Development of MSEs of Sintrong Leaf Chips in Cilacap District".

MSME development in the Cilacap area has not yet been accommodated for all. whereas this SMEs will raise the welfare of business actors by utilizing the creativity of the community. In the current pandemic, the MSME sector is very resilient because of the easy use of local resources. so that it will raise the national economy. Based on the authors' research so far, there has not been a research done about the development of MSEs of Sintrong Leaf Chips in Cilacap. Therefore, conducted research is authentic.

Previous research on Sintrong leaf chips has not been found. But research on the content contained in Sintrong leaves has been carried out by Gaty Safita et al., 2015 who examined Sintrong leaves as an anti-bacterial for the treatment of ISPA (Infeksi Saluran Pernafasan Akut) which has a $\mathrm{khm}$ of 9,000 and 8,000 against certain bacteria. Besides that, it is also said that in Africa Sintrong leaves are not only used as food ingredients but are used as ingredients in traditional medicines (Grubben and Denton, 2004 (Gaty et al, 2015). [5]

Another previous research on Sintrong leaf was conducted by Imas Yummiati et al., 2016 who examined the analgetic activity test of sintrong leaf (Crassocephalum Crepidioides (Benth) S.Moore) ethanol extract against mice male DDY Line. The research found that Sintrong leaf has analgesic actvity which has been tested on mencit using jentik ekor method. [6]

Both of the previous research put emphasize on the activity testing of Sintrong leaf as antibacterial to cure ISPA and analgesic activity testing from extract etanol of Sintrong leaf on male mencit, while on this research, the authors focused on the development efforts of MSEs entrepreneurs of Sintrong leaf chips in Cilacap District where its improvement still face many obstacles.Sintrong leaf chip business starts from a housewife who uses Sintrong plants in the area where she lives, so the people there are interested in making Sintrong leaves into chips and can be sold in the market to increase family income. These Sintrong leaf chips began to be made and distributed immediately to local stalls for sale and some relatives in the big city have started placing orders. The processing of Sintrong chips has only been carried out in Kuta Agung from 2014 to the present. For the sustainability of the community, Sintrong leaf business actors really need to focus on planting their plants so as not to experience a shortage of raw materials.

There are several obstacles faced by Sintrong leaf chip processors, starting from limited human resources, simple packaging techniques and local marketing, limited capital from the personal pockets of this Sintrong leaf producer. Therefore, the researcher wants to explore the business of Sintrong leaf by analyzing it from the internal and external potential as well as the obstacles faced in the development of this Sintrong leaf. so that it can develop into an MSME business that can compete in the business world and the need for attention from the local government to support and increase community income.

\subsection{Formulation of Problems}

a. How do we describe and analyze the development of MSEs in the business of Sintrong Leaf Chips in Cilacap District?

b. How do we describe and analyze the obstacles in the development of MSEs in the business of Sintrong Leaf Chips in Cilacap District? 


\subsection{Objectives of Problems}

a. To describe and analyze the development of MSEs in the business of Sintrong Leaf Chips in Cilacap District.

b. To describe and analyze the obstacles in the development of MSEs in the business of sintrong leaf chips in Cilacap Distrik.

\section{Literature Review}

\subsection{Product Development}

According to Kotler and Armstrong, 2008 (Endang, 2013) product development is developing a product concept into a real product to ensure that product ideas can be turned into workable products. Product development is a cross-disciplinary activity that requires contributions from almost all functions in the company, but the three functions are always the most important for a product development project, namely: Marketing, Design, and Manufacturing. The stages of new product development are creating ideas, filtering ideas, developing and testing conceptual ideas. [7]

The Development Of Micro, Small and Medium Scale of Enterprises According to the Presidential Decree of the Republic of Indonesia Number 99 of 1998, it explains that "small business is a small-scale economic activity of the people with field of business mostly as small business activity and it needs to be protected to avoid from unhealthy business competitiveness". [8]

On Feni etc, 2014 explanation about article 19 of Law 20/2008 concerning MSMEs, development in the HR field as in Article 16 paragraph (1) letter $\mathrm{c}$ is carried out by:

a. promoting and empowering entrepreneurship;

b. improve technical and managerial skills.

c. establish and develop educational and training institutions to conduct education, training and counseling, motivation, business creativity and the creation of new entrepreneurs. [9]

\subsection{The Concept of Micro, Small and Medium Scale of Enterprises (MSEs)}

According to Chapter I Article 1 of Law Number 20 of 2008 on Micro, Small and MediumScale of Enterprises (MSME), such Micro, Small and Medium Scale of Enterprises are defined as follows:

a. Micro business is a productive business of an individual person and/or individual business entity that meets criterion of micro business as regulated in this law.

b. Small business is a productive economic business that stands alone which is conducted by an individual person and/or business entity which is not a subsidiary or branch of the company owned, controlled or became part both directly and indirectly of Medium or Large Business that meets criterion of small business as intended in this law.

c. Medium business is a productive economic business that stands alone which is conducted by an individual person or business entity which is not a subsidiary or branch of the company owned, controlled or became part both directly and indirectly with small or large business with total net assets or annual sales revenue as regulated in this law. [8]

2.3 Law Number 20 of 2008 concerning Micro, Small and Medium-Scale of Enterprises. 
Based on the above definition, Micro, Small and Medium-Scale of Enterprises is basically a form of productive economic business which is conducted by an individual person or business entity that meets criterion of Micro, Small and Medium-Scale of Enterprises.

\subsection{Sintrong Leaf}

Sintrong that has scientific name of crassocephalum crepidiodes is "a kind of plant of member of Asteraceae family. This plant is commonly found wild as weeds at roadside, at yard and on the deserted land and it grows on the elevation above 200 meters above the sea level. In Indonesia, this plant is called junggul, bagini, jambrong, tespong (Sundanese), jombloh, mandrung-mandrung, puyung and taplek (Javanese)".

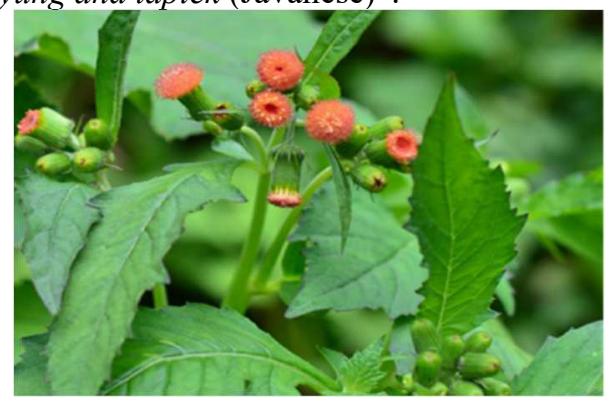

Fig.2. Picture of Sintong plant

Sintrong grows upright and up to 1-meter height. It smells aromatic fragrant if it is squeezed. It has soft trunk with shallow grooved. The leaves have been spreaded over with stalk which is often eared. Strands of leaves are ellypse stretched or inverted round egg with a size of 8-20 x 3-6 cm with the trunk is gradually narrowing along the stalk of leaf and its pointed end, flat or dented edge up to sharing pinnate, having big and pointed jagged teeth where the leaf located above is smaller and it often sits. [10]

a. Ecology and Distribution of Sintrong Leaf

Sintrong has the origin from tropical Africa and now it has been spread over the territory of tropical Asia, including Indonesia. In Indonesia, these weeds were found for the first time in Medan in 1926 and then they were brought to Java areas and now they are spreading in all over Indonesia islands. These weeds have flowers and its spreading is supported by wind. These weeds are categorized as disturbing plants, but they are easily handled.Sintrong leaf is not only useful for salad and vegetables, but also as traditional medicine. Such traditional medicine is used to handle stomach disorder, headache, wound ,and so on. Sintrong leaf is slightly astringent and neutral as well as anti-inflammatory, hemostatic, laxative, vomiting stimulant and tonic. This herbal plant is used for tonsillitis, fever, eczema, and animal feed.

b. Meaning of Sintrong Leaf

Sintrong has many names from jambrong, balastrong, tespong, sawi rusa, jebung and so on. Sintrong leaf has benefits in Indonesia not only processed into vegetables, but also for animal feed. Sintrong has tender texture because its trunk is really soft. The smell of sintrong leaf is also tasty which is like mint leaf. The taste is quite neutral and matched in the mouth so that everyone will certainly like it.

c. Contents and Benefits of Sintrong Leaf

Sintrong leaf mostly contains important nutrition from polyphenol, saponin and flavonoide as strong anti-oxidant that has function to neutralize free radical (reactive oxygen species) and reduce the level of damage on body cells. Also, sintrong leaf also contains essential oil, vitamin 
and mineral which are efficacious for the body. It also contains vitamin and anti-oxydant that effectively help decreasing the risk of cancer.

Sintrong leaf has these following great benefits:

1) Treat cancer disease.

Sintrong leaf contains vitamin and anti-oxidant that effectively help decreasing the risk of cancer, either heart, breast and gastric cancers.

2) Hypertension

Sintrong leaf can lower high blood pressure and help to keep its blood pressure to be normal.

3) Gastric acid

Sintrong leaf helps to neutralize gastric acid and to strengthen gastric muscle so that the function can be more optimal.

4) Strengthen bones

Sintrong contains magnesium that has function to strengthen bones and maintain its density.

5) Make smooth of digestive system.

Sintrong contains natural fiber and other important nutrition that effectively clean its the digestive system so that it avoids from a disturbing problem.

6) Improve the immunity system of body.

Sintrong may not only contain rich in anti-oxidant, but also anti-bacterial, anti-germs and anti-inflammation that effectively increase the immunity system of body.

7) Reduce the content of bad cholesterol.

Consuming sintrong leaf is beneficial to decrease the content of bad cholesterol and increase the content of good cholesterol so that the body will be healthier.

8) Relief the pain.

Sintrong leaf can be efficacious as an analgesic and antipyretic that help relieving the pain or hurt on the parts of the body, such as: headache, back pain and so on. [10].

\subsection{Sintrong Chips}

Some previous researches that can be used as references are Feni et all research entitled Sintrong leaf chips have just been made in Kuta Agung Village, Dayeuhluhur Sub-District, Cilacap District starting from 2014 with an initial purpose to be directly consumed because it has benefit for ulcer and stomach ache drugs. When time passes by, it starts to be marketed in local stalls nearby the house. These sintrong leaf chips are made by a housewife nearby the house where many sintrong leaves grow in that area. [4]

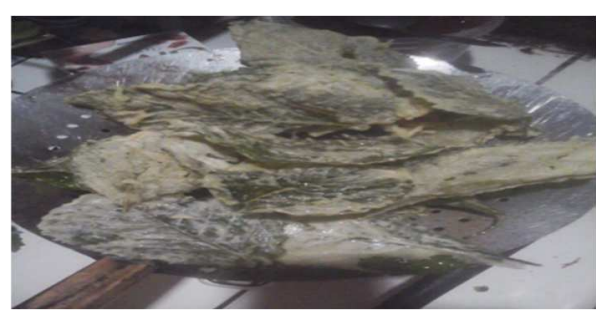

Fig.3. Sintrong leaf chips

Development of Small and Medium Enterprises (MSMEs) through external facilities and internal potential stating that internal development of the bussines group" Emping Jagung" in increasing the potential with an initial capital pay using there on savings, to innovate their product, expanding the marketing network, and complement its infrastructure. In addition, the facility from external cooperative and SMEs in Malang have giving SMEs access to capital 
resources, conducting coaching and training, product promotion activities, expand product marketing, as well as providing facilities and infrastructure. [5]

Other research references are Retno Kusumastuti entitled "Innovation diagnostic of micro, Small and Medium Enterproses (SME) : A comparative study of innovation process of SMES in Depok and Solo“. This study aims to analyze innovation diagnostic in micro, small, and medium enterprises in Depok an Solo. The findings of the study show SMEs as an active innovator by presenting the profile of SMEs and the perception of the context of existing innovations. The obstacles in innovation learning are related to human resources, the implementation of technology and the access to capital [11]

We have not found research on Sintrong leaf chips before, but research on the content of Sintrong leaves has been conducted by Gaty et al., 2015 which states that Sintrong leaves have high antibacterial properties. Therefore, we are interested in the development of Sintrong leaves to be processed into Sintrong leaf chips to add to the economic value of Sintrong leaves itself. By developing Sintrong leaf processing, the leave sintrong chips craftsmen will advance MSMEs in Cilacap Regency. Research on MSMEs by looking at previous research on the development of MSMEs against Corn Chips chips carried out by FENI et al, the development of Sintrong leaf MSMEs can also be done in Cilacap Regency by looking at the potential in the area.

In previous research by Dwi, 2013 regarding product development from internal and external which provided information on the internal potential for product development from MSME Corn chips. By looking at housewives who use Sintrong leaves as a food ingredient and processed interestingly so that it will produce added value to the Sintrong leaf product, the first hypothesis in this research is:

H1 : There is an internal and external potential for the development of Sintrong leaf chips MSMEs

In developing a business, not everything goes instantaneously but there are many stages that must be passed. in accordance with previous research in the development of corn chips conducted by Dwi, 2013 that there are several obstacles in developing corn chip products. by knowing that there are obstacles, an effort will continue to fix them for the progress of the business. So, the second hypothesis is:

H2 : Obstacles to the development of sintrong leaf chips MSMEs in Kuta Agung Village, Dayeuhluhur District, Cilacap Regency.

\section{Method}

This research is conducted in Kuta Agung Village, Dayeuhluhur Sub-District, Cilacap District purposively by considering this area as the first initiator of the making of business of sintrong leaf chips in Cilacap District. This research was conducted from May to july 2020. Samples taken amounted to three people, two people from the Sintrong leaf business group and one from the UKM office. The sampling technique was a purposive sampling method. Data is collected with questionnaires which are performed through interview by the researcher. Resource persons being interviewed in this study consist of three (3) persons as follows:

a. Section Head of Empowerment of Indusries, Cooperatives Office, MSEs, Industry and Trade of Cilacap District.

b. Chips Entrepreneur who is also the Head of Joint Business Group in Kuta Agung Village.

c. Chips Entrepreneur as the Management of Bumdes in Kuta Agung Village. 
These three (3) respondents are selected because they have good corelation, knowledge and qualified experience on the topic to be studied which is sintrong leaf chip. Such expert's knowledge and experience hopefully may give good information so that it can answer the objective of this research.

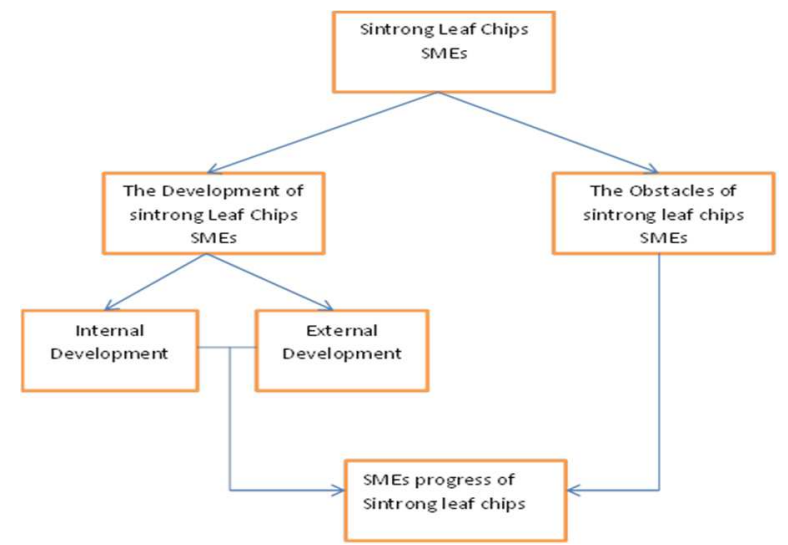

Fig.4. A frame work of research The Development of Sintong leaf chips SMEs

\section{Data Processing and Analysis}

The method used here is a descriptive-qualitative analysis with a framework show in fig.4. The method of data processing and analysis in this study is focused on:

The developments of MSEs through internal potency and external factor of MSE of sintrong chips in Kuta Agung Village, Dayeuhluhur Sub-District, Cilacap District that consist of:

1) Internal development of MSE of sintrong leaf in Kuta Agung Village, Dayeuhluhur SubDistrict, Cilacap District, namely:
a. Supply of raw materials.
b. Providing capitalization.
c. Product introduction.
d. Marketing network expansion.
e. Procurement of facilities and infrastructures.
f. Product packaging.

2) External developments of Cooperatives Office and MSEs of Cilacap District, are as follows:
a. Giving access to MSEs in capitalization.
b. Providing coaching and training.
c. Increasing promotion and expansion of product marketing.
d. Facilitation of licensing.
e. Providing facilities and infrastructures.

The obstacles of the development of MSEs of Joint Business Group of Sintrong Leaf Chips in Kuta Agung Village, Dayeuhluhur Sub-District, Cilacap District, include:
a. Limited human resources.
b. Have limited capitalization.
c. Minimum access to product marketing.
d. Limited facilities and infrastructures.
e. Introduction of a new product. 
f. Packaging is still simple.

Data analysis in this research is based on Miles and Huberman, 1984 (Alfiah, Jeni, Anah 2020) [12] and in (Feni etc, 2013) [9]:

a. Data collection is a process of collecting data used to support the result of this study.

b. Data reduction is a process of selection, focusing attention on simplification, making abstract and transformation of raw data arising out of written notes at field. Data reduction takes place continuously as long as such qualitative study-oriented project is ongoing.

c. Data presentation is an activity of presenting sets of information in form of narrative texts supported with graph, table and chart that have a purpose to sharpen the understanding of researcher toward such information.

d. Concluding is finding the meaning, patterns, explanation, possible configuration, causal flow and proposition. Concluding is also made carefully and it is also verified, namely reviewing on field notes so that the validation of existing data is tested.

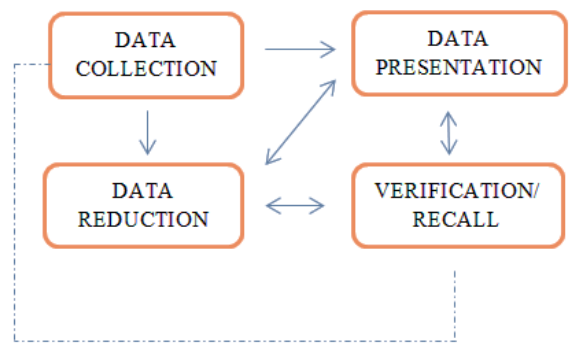

Fig.5. Analysis Model of Interactive Data of Miles and Huberman

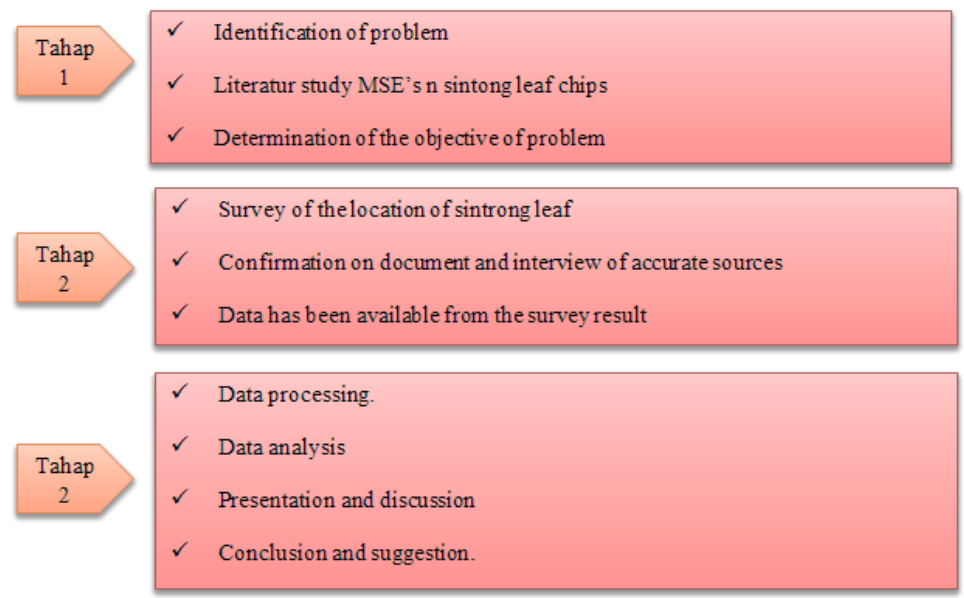

Figure 6 : Flow Chart of the Research

\section{Result And Discussion}


a. The development of Micro and Small Scale of Enterprises is performed through facilities of the internal and external party in MSE of sintrong leaf chips in Kuta Agung Village, Dayeuhluhur Sub-District, Cilacap District.

MSE is a small-scale business of Indonesian people that really helps making prosperous of its entrepreneurs. More active movement of the existing MSE in Indonesia will support the stability of the economy in this country. People have started to have creation sensitively toward valued products that originate from its surrounding environment.

This MSE will develop more and more if it has support from all parties, including the Government by giving facilities that will be used by MSE actors to support their business implementation and advancement in order to produce competitive quality of production and to enter an international business world. As disclosed by the United Nations (PBB) by Lz. A.Einsiedel, 1968, h.9 (Feni Dwi, etc, 2013) that "building society is a process where businesses or potencies owned by the society are integrated with resources owned by the Government in order to improve the economic, social and culture conditions and to integrate the people in the context of life of the nation as well as empower them in order to be able to give full contribution to achieve progresss at national level. [9]

\section{1) The development of Internal Small and Medium-Scale of Business of Sintrong Leaf Chips in Kuta Agung Village, Dayeuhluhur Sub-District, Cilacap District.}

Sintrong leaf chips started to be produced by farmers in Kuta Agung Village in 2012. The farmers producing these sintrong leaf chips are still very few because of not having the knowledge on its contents and less creativity of farmers toward sintrong leaf which mostly grows in Kuta Agung Village. The potencies and developments owned and performed by the entrepreneurs of sintrong leaf chips in Kuta Agung Village, Cilacap District are as follows:

a) Supply of raw materials.

Raw materials of sintrong leaf plants easily obtained in Kuta Agung Village give inspiration for the pioneer to process them into chips. Kuta Agung Village is located at suburbs of Cilacap District where it still has many forests so that there are so many plants of those sintrong leaves so that it comes to an idea to make the chips and then it is sold as the source of income for those entrepreneurs.

b) Creativity of farmers

The potency owned by farmers to make such sintrong leaf into chips and then it is sold and packed in such a way is a high creativity for the economic advancement of the villagers so that it will be influential to share such creativity to other people. The existence of this micro and small business will help making economic advancement of at district, regional and even national level.

c) Providing capitalization

Capitalization used by the entrepreneurs of this MSE of sintrong leaf chips is using their own saving money.

\section{d) Product introduction}

entrepreneurs of sintrong leaf are really just making his/her own production and there are no such other productions of sintrong leaf chips before. The product of sintrong leaf chips is usually for their own consumptions, but due to such raw materials are so many so that they think an idea to be sold and then they start introducing it to the people in Kuta Agung Village 
themselves and then it continues to the neighbor village and other districts. This introduction effort needs persistence because it is a brand new business.

e) Marketing network expansion

The first marketing of sintrong leaf chips is conducted by depositing it at the stalls nearby houses in Kuta Agung Village with a small packaging and tagged with a price of Rp 5.000,which is adjusted with power of purchase of the people surround it. Later, there comes order from the neighbor village for food snacks as a gift and then they bring them to their own cities. It starts having quite expansive marketing which is also supported by social media. Within a month, MSE of sintrong leaf chips in Kuta Agung Village has produced about $70 \mathrm{~kg}$ of chips where the price is Rp 30.000,- per kilogram. Upon this business having been growing, MSE of sintrong leaf chips are categorized in a business forum of the village, namely Usaha Peningkatan Pendapatan Keluarga Sejahtera (UPPKS). UPPKS is an abbreviation of Business of Improving Income of Prosperous Family.

f) Providing facilities and infrastructures

Facilities and infrastructures still use household furniture as they are and those furnitures are still traditional and simple. For marketing purpose, it still deposits in the nearby stalls that do not have its own shops.

g) Product packaging

Product packaging that has been performed is still very simple, namely using common plastic packaging and traditional glue. Certification and license are not yet existed so that such packaging of sintrong leaf chips is still so minim. [4]

\section{2) Development and Coaching of External Product of MSE of sintrong leaf chips in Cilacap District}

The Government's role in the effort of developing MSE is really needed because MSE is one of potential efforts in advancing the economy of local people, advancing the economy and prosperity of people of Cilacap District in general. People empowerment, in this case empowering local resources, improving human resources and providing facilities and infrastructures will support product development of sintrong chips. The development of MSE mostly gives benefit either for micro business actor and district government, namely it can develop local potency. As we have known that before such sintrong leaf growing wild may not have any benefits, but after it is processed, it turns out to become processing foods which are not only tasty, but also beneficial for our health because sintrong leaf has some benefits for our health other than hirng workers and reducing unemployment rate and finally reducing poverty.

Actualizing prosperious people is the aspiration of Government, both central and district goverment, so that various efforts are continuously conducted by the Government at present, including one of them is doing empowerment and development of MSEs, especially micro and small enterprises in order such micro enterprises is being empowered and developed as well as upgraded. It also makes small business can develop into a medium business. As we have known that "Micro business is classified into a marginal type of business due to the use of relatively simple technology, low level of capital, a minim access to credit and having orientation more on local market.

Therefore, it should always be managed a proper strategy to empower MSEs so that the people's prosperity is increased accordingly (Ferry Duwi, 2014). [13] In order to be able to increase the capability of MSE and empower it as well, it needs a role of relevant party, among others Cooperatives Office and MSE of Cilacap District as the extension of District Government in order to be able to overcome the obstacles and problems faced by most of business actor of 
micro and small scale of business, either in term of human resources, capitalization, management, marketing, facilities and infrastructures.

a) Access to Capitalization for Business Actor of Sintrong Leaf Chips

Most of MSE in running business generally meets financial need by relying on his/her own capital with limited amount of money. Even they often forced to borrow the money for a business purpose from a loan shark with a very high interest to meet their capital needs because they do not meet the requirement of bank so that they look for their own financing solution.

It has relatedness with giving business capital support for MSE upon the existence of Regulation of the Minister of Home Affairs Number 14 of 2016, especially Article 4 paragraph 4 point c stating that "grant fund support may not be given continuously every annual budget", then Cooperatives Office and MSEs Cilacap District have obstacle in their effort of giving fund support in form of grant, especially for empowerment of MSE so that the coaching and empowerment for MSEs, especially MSEs are given in other forms, namely management and marketing facilitation.

Up to date, micro business actors in producing sintrong leaf may not have any access of capital support from relevant government service and they still use capital from their own money. In the meantime, due to the empowerment of MSEs Cilacap District, the Members of Regional House of People Representatives (DPRD) Cilacap District also perform many efforts in the empowerment of MSEs, among others by proposing an issuance of District Regulation on the Empowerment of MSEs at Cilacap District, as well as submitting a proposal on budgeting support for the empowerment of MSEs which is allocated for various kinds of technical training for MSEs, certification and licensing for MSEs.

b) Mentoring and training for micro and small business actor of sintrong leaf

Mentoring and training are conducted by Cooperatives Office and MSEs is a form of partiality of District Government in advancing and developing MSEs in Cilacap District. This government support will encourage and motivate micro business actor to keep developing his/her business. In handling such problem, Cooperatives Office and MSEs Cilacap District have owned a service unit for the empowerment of MSE, namely Integrated Business Service Center - The Ministry of Cooperatives and MSEs.

Pusat Layanan Terpadu (PLUT) MSMEs in this Cilacap District provides non-financial service for MSMEs where it has purpose to improve the performance of production, marketing and access to financing, development of human resources through the improvement of entrepreneurship capacity, technical and managerial as well as institutional performance in increasing competitiveness. By having this PLUT MSMEs, it hopefully can give technical mentoring for all MSEs without exception for micro and small business of sintrong leaf of which its business has run at average since 2012. Thus, all business actors of MSEs in Cilacap District who still have obstacle in developing their business products can make use of such facility of mentoring and consult at PLUT MSMEs. And so as District Government needs to keep doing massive socialization to all business actors in Cilacap District, so that many people will know such programs of micro and small business products.

Mentoring and training for business actor for superior product in Cilacap District have been conducted such as training for business actor of brown sugar, coffee, smoked or dried banana fritters, tengiri chips, processing food from sea fish that has been performed periodically. But then, business mentoring and training for micro business actor of sinkrong leaf chips may not yet be performed up to date. 
The training of making sintrong chips has been performed by Government Service of of Pemberdayaan Perempuan dan Perlindungan Anak (PPPA) and Petugas Lapangan Keluarga Berencana (PLKB) Cilacap District in a very limited number. The limitation of human resources of business actors of sintrong leaf chips from the aspect of formal education and knowledge as well as capability of business actor is really influential in managing their business, so that their business is difficult to be developed optimally. In addition, limited knowledge and mastery toward technology also have impact in advancing their business and increase its business competitiveness.

Cooperatives Office and MSEs Cilacap District through PLUT MSMEs also have supported to facilitate for the making of basic license for small and micro business or Ijin UsahaMikro Kecil (IUMK), including help connecting business actors with Government Service of Industry and Trade, Government Service of Health and Regional Office of Religion in order to obtain a certification in form of PIRT, and a halal certification from MUI. Thus, program and coaching from relevant party and government service are really needed for business actors of sintrong chips to advance their business.

c) Product introduction/promotion and product marketing expansion

The efforts to advance business actors of MSE in Cilacap District, Cooperatives Office and MSE have help facilitating most of the MSE actors by participating in various activities, both in Cilacap District or attending the exhibition activity in other regions, such as the exhibition during National Cooperative Day which is held every year in many cities. Cooperatives Offices and MSE may not only facilitate in various activities and exhibitions, but also ask small and micro business actors to join in the Association of Micro and Small Business Actor at provincial level. This association is really beneficial for micro business actor. It is not only as a forum of joining of micro and small business actors, but also quite effective in obtaining information access and MSE empowerment program at provincial level which is very useful for micro and small business actors, especially for micro and small business actors who have just grow and develop.

Up to date, micro enterprises actors for the production of sintrong leaf have just obtained two times of access to product promotion and marketing, namely by attending an exhibibition in two (2) sub-districcts, namely Dayeuhluhur Sub-District and Wanareja Sub-District in an event held by its own sub-district. In addition, such products are still marketed locally, either in the stalls or local market. The products are also marketed by using online media such as FaceBook, instagram and whatsapp.

d) Access to facilities and infrastructures for MSEs of Sintrong Leaf Chips.

Cooperatives Offices and MSE in an effort of empowerment of MSME may not give support of equipment, facilities and infrastructures for micro enterprises actors because it is under domain of Industry and Trade Department. At present, micro and small business actors of sintrong leaf chips still have obstacle in providing deep fryer of sintrong chips. In the condition of such limited facilities and infrastructures, they can produce sintrong leaf chips of $70 \mathrm{~kg}$ every month with the price of Rp.30.000 per $1 \mathrm{~kg}$. Thus, upon optimization of resources for MSEs, sintrong leaf chips have huge potency to be developed and it is supported by the availability of raw materials which are easily found in that village. [14]

b. The obstacles of micro and small enterprises development of sintrong leaf chips in Kuta Agung Village, Dayeuhluhur Sub-District, Cilacap District. 


\section{1) Limited human resources}

Human resources in business activity are very important factor because they are the driver of business activity and where to bring such business in the future. Based on the result of this research, the entrepreneurs of sintrong leaf chips have limited knowledge and skill to develop business of sintrong leaf more extensive and competitive in modern market. Innovation and creation to become a competitive product in the market are also necessarily given direction and training.

\section{2) Have limited capitalization}

The entrepreneurs really need capital if they will start doing business. The interview result with sintrong leaf chips entrepreneurs indicates that they use their own money to run such business. The money is taken from their own-savings and even they tend to have difficulty, but it may not demotivate them to start doing business of sintrong leaf chips because they see that such raw materials are easily found in their village. Sintrong leaf chips entrepreneurs really hope that they get capital support from the Government to expand their business in the future.

\section{3) Minim access to product marketing}

Marketing access in business is important factor because customers will know the product if such marketing access arrives fast at customers. MSEs of sintrong leaf chips have conducted marketing to the closest stalls and through online media such as facebook, Instagram and Whatsapp. Having not been supported by the signal of internet provider in that village also disturbs the communication with customers. In addition, a quite far of distance from the end of sub-district to the city makes an obstacle for transportation. Many consumers surrounding still do not know the production of sintrong leaf chips. MSEs of sintrong leaf chips really hope for marketing and promotion support from the Government so that their products are quite known by the people and it becomes specific characteristic of such Kuta Agung Village. MSEs have ever attended exhibition in two (2) sub-districts twice in the event held by Dayeuhluhur SubDistrict and Wanareja Sub-District. MSEs are very enthusiastic in that event so that they hope to continuously being participated in the exhibitions held in the districts or regencies as a way of promotion of such MSE product of sintrong leaf chips.

\section{4) Limited facilities and infrastructures}

Facilities and infrastructures are important factors in supporting the development of MSE. Facilities and infrastructures in a business should support for the smoothness of production so that it produces qualified and competitive products. Sintrong leaf chips entrepreneurs do not have a special place of production, but they produce in their own houses so that there is not too much cost to be expensed. They use very traditional equipment that they have as it is in the house in order to avoid more cost. For example, frying is still minim and they do not have any chips drier. For marketing means, MSE entrepreneurs of sintrong leaf chips may not have any shops yet, but they still deposit their products in the stalls nearby. Therefore, these obstacles faced in facilities and infrastructures may cause the production of sintrong leaf chips not so optimal.

\section{5) Introduction of new product}

New product is a product which is made for the first time and there is no such product before, so that the people do not know it. Sintrong leaf chips are new product in territory of Dayeuhluhur Sub-District and it is developed and produced for the first time in Kuta Agung Village. Thus, it needs extra struggle that should be conducted by entrepreneurs producing such new product. 
The entrepreneurs conduct various efforts in order such sintrong leaf chips are accepted and known by people so that the people will purchase it again. If there is an exhibition or event outside of the village, MSEs entrepreneurs always bring such products as food snacks for gift as well as the promotion of such product of sintrong chips.

\section{6) Packaging is still simple.}

A product will look interesting if it is packed well, neatly and competitive in the market and safely consumed. These sintrong leaf chips are still packed in common plastic that still uses traditional tools so that it is still packed very simple. The glue is still very simple and the label is also still simple. There are no certification and licensing on the product of these sintrong chips, so that it is really necessary to help facilitating in such certification and licensing.

\section{Closing}

A product will look interesting if it is packed well, neatly and competitive in the market and safely consumed. These sintrong leaf chips are still packed in common plastic that still uses traditional tools so that it is still packed very simple. The glue is still very simple and the label is also still simple. There are no certification and licensing on the product of these sintrong chips, so that it is really necessary to help facilitating in such certification and licensing.

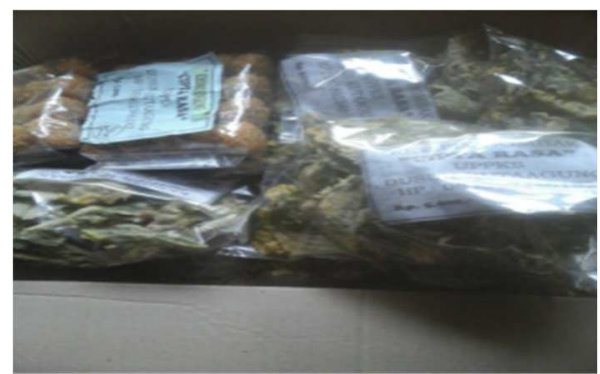

Fig.7. The Packaging of Sintrong Chips

\section{Conclusion}

1) The development of Micro and Small Enterprises (MSEs) through facility of internal party in MSEs sintrong leaf chips in Kuta Agung Village, Dayeuhluhur Sub-District, Cilacap District, consists of:
a. Supplying raw materials
b. Creativity of farmers
c. Providing capitalization
d. Introduction of product
e. Marketing network expansion
f. Providing facilities and infrastructures
g. Product packaging

2) The development and coaching of external product of MSEs sintrong leaf chips in Cilacap District are conducted as follows:

a. Access to capitalization for business actor of sintrong leaf chips 
Up to date, micro business actors in the production of sintrong leaf may not have any access of capital support from relevant government services and they still use their own money as the capital.

b. Mentoring and training for micro and small business actor of sintrong leaf

Training of the development of MSME has been conducted by Government Services of PPPA and PLKB Cilacap District in a very limited number. Limited human resources of enterprises of sintrong leaf chips from the aspect of formal education, knowledge and skill is really influential in managing its business, so that their businesses are difficult to develop optimally. In addition, such limited knowledge and mastery toward technology also have impact in advancing their business and increasing its business competitiveness.

c. Product introduction/promotion and product marketing expansion

Up to date, micro enterprises in the production of sintrong leaf have just obtained access two times toward product promotion and marketing by conducting the exhibition in two subdistricts in the event held by its their sub-districts. The products are still marketed locally, both in the stalls or local market. It is also marketed by making use of online media such as Facebook, Instagram and Whatsapp.

d. Access to facilities and infrastructures for MSEs entrepreneurs of sintrong leaf chips. Cooperatives Offices and MSEs in the effort of MSEs empowerment do not give any support of equipment, facilities and infrastructures for micro business actors because it is under doman of Industry and Trade Department.

3) The obstacles of development of micro and small enterprises of sintrong leaf chips in Kuta Agung Village, Dayeuhluhur Sub-District, Cilacap District are as follows:

a. Limited human resources

b. Have limited capitalization

c. Minim access to product marketing

d. Limited facilities and infrastructures

e. Introduction of new product

f. Packaging is still simple

The Government has commitment to develop MSEs sintrong leaf chips in facilitating the capitalization, facilities and infrastructures to help the development of MSEs and improve people's prosperity as well as advance the economy in Indonesia.

The entrepreneurs of sintrong leaf chips should cultivate raw materials of sintrong leaf to keep moving and continuing by always having the availability of raw material.

Technical training is conducted to increase the capability of MSEs of sintrong leaf so that they can develop their business, from the training of business management up to online marketing.

Optimization of the role of PLUT in order to empower MSMEs more effectively in Cilacap District and update the number of existing MSMEs in all Cilacap District so that it is easier and efficient to give such training.

It needs facilitation from Cooperatives Offices and Industry Department related to certification and licensing such as PIRT, IUMK and Halal MUI so that the products of sintrong leaf chips can compete with other products in the market.

\section{Reference}


[1] BKP Pertanian, "Rencana Kerja Tahunan Badan Ketahanan Pangan Tahun 2019," BKP Pertanian, 2019. [Online]. Available: Rencana Kerja Tahunan Badan Ketahanan Pangan http://bkp.pertanian.go.id/storage/app/media/PPID\%202019/RKT\%202019.pdf. [Accessed 15 July 2020].

[2] Dinkop UMKM Jawa Tengah, "Percentage Graph of Type of MSME's under Guidance of Central Java Province (2008-2018)," Dinkop UMKM Jawa Tengah, 2019. [Online]. Available: https://dinkopumkm.jatengprov.go.id/resc/img/media/2655grafik_jenis_usaha_tw_i_2019.jpg. [Accessed 20 July 2020].

[3] A. Wijaya, "http://permathic.blogspot.com/2016/08/manfaat-dan-khasiat-daun-sintrong-bagi.html," permathuc.blogspot.com, August 2016. [Online]. Available: http://permathic.blogspot.com/2016/08/manfaat-dan-khasiat-daun-sintrong-bagi.html. [Accessed 20 July 2020].

[4] D. Daryati and W. , Interviewees, Sintrong leaf chip businesswomans. [Interview]. 10 July 2020.

[5] G. Safita, E. R. E. Sakti and L. Syafnir, "Gaty Safita, Endah RismUji Aktivitas Antibakteri Daun Kenikir (Cosmos caudatusKunth.) dan Daun Sintrong (Crassocephalum crepidiides ( Benth.) S. Moore.) terhadap Bakteri Staphylococcus aureus dan Pseudomonas aeruginosa," in Prosiding Penelitian SPeSIA UNISBA, West Java, 2015.

[6] I. Yumiati, U. Yuniarni and S. Hazar, "Imas YumniatUji Aktivitas Analgetica Ekstrak Etanol Daun Sintrong (crassocephalum crepidiodes (Benth.) S. Moore) Terhadap Mencit Jantan Galur DDY," in Prosiding Farmasi Unisba, West Java, 2016.

[7] E. S. Rini, "Peran Pengembangan Produk Dalam Meningkatkan Penjualan," Jurnal Ekonom, Vols. Vol 16, No 1, no. Product developement, 2013.

[8] OJK, "https://www.ojk.go.id/sustainable-finance/id/peraturan/undang-undang/Pages/UndangUndang-Republik-Indonesia-Nomor-20-Tahun-2008-Tentang-Usaha-Mikro,-Kecil,-danMenengah.aspx," OJK, 3 April 2017. [Online]. Available: https://www.ojk.go.id/sustainablefinance/id/peraturan/undang-undang/Pages/Undang-Undang-Republik-Indonesia-Nomor-20Tahun-2008-Tentang-Usaha-Mikro,-Kecil,-dan-Menengah.aspx. [Accessed 15 July 2020].

[9] F. D. Anggraeni, I. Hardjanto and A. Hayat, "Pengembangan Usaha Mikro, Kecil, Dan Menengah (UMKM) Melalui Fasilitas Pihak Eksternal dan Potensi Internal.“ in Jurnal Administrasi Publik (JAP), 2013, Vol. 1, No. 6, p. 1288," Jurnal Administrasi Publik (JAP), vol. Vol. 1 No. 6, p. 1288, 2013.

[10] Aryanto, "http://surabayapagi.com/read/manfaat-sehat-sintrong-yang-sering-dianggap-rumputliar," surabayapagi.com, 27 March 2018. [Online]. Available: Aryanto. „Manfaat Sehat Sintrong yang Sering Diangghttp://surabayapagi.com/read/manfaat-sehat-sintrong-yang-sering-dianggaprumput-lar. [Accessed 22 July 2020].

[11] R. Kusumastuti, "Innovation diagnostic of micro, Small and Medium Enterproses (SME) : A comparative study of innovation process of SMES in Depok and Solo," Retno Kusumastuti. "Innovation diagnostic of micro, Small and Medium Enterproses (SME) : A comparative study of International Journal of Applied Business and Economic Research., vol. nternational Journal of Applied Business and Economic Research, no. SMEs, p. 597, 2017.

[12] S. Alfiah, J. Andriani and A. Furyanah, "AlfEfektifitas Pengelolaan Lokasi Wisata Curug Paog dan Bukit di Subang Jawa Barat," Alfiah, Jeni Andriani, Anah Furyanah. „Efektifitas Pengelolaan Lokasi WJurnal Pemasaran Kompetitif, Vols. 03, nO. 2, no. SMEs, p. 70, 2020. 
[13] F. Kurniawan and L. Fauziah, "Ferry,,Pemberdayaan Usaha Mikro Kecil dan Menengah (UMKM) Dalam Penanggulangan Kemiskinan," JKMP, vol. 2 No. 2, no. SMeS, p. 1Ferry Duwi Kurniawan Luluk Fauziah. „Pemberdayaan U, 2014.

[14] Mahmudin, Interviewee, InHead of Section for Empowerment of Development and Quality Improvement of Cooperative HR in Dayeuhluhur Sub-District, Cilacap District. [Interview]. 22 July 2020.

[15] G. Safita, E. R. E. Sakti and L. Syafnir, "Uji Aktivitas Antibakteri Daun Kenikir (Cosmos CaudatusKunth.) dan Daun Sintrong (Crassocephalum Crepidiides ( Benth.) S. Moore.) terhadap Bakteri Staphylococcus aureus dan Pseudomonas aeruginosa," in Prosiding Penelitian SPeSIA Unisba, West Java, 2015.

[16] I. Yumniati, U. Yuniarni and S. Hazar, "Uji Aktivitas Analgetica Ekstrak Etanol Daun Sintrong (crassocephalum crepidiodes (Benth.) S. Moore) Terhadap Mencit Jantan Galur DDY," in Prosiding Farmasi Unisba, West Java, 2016. 